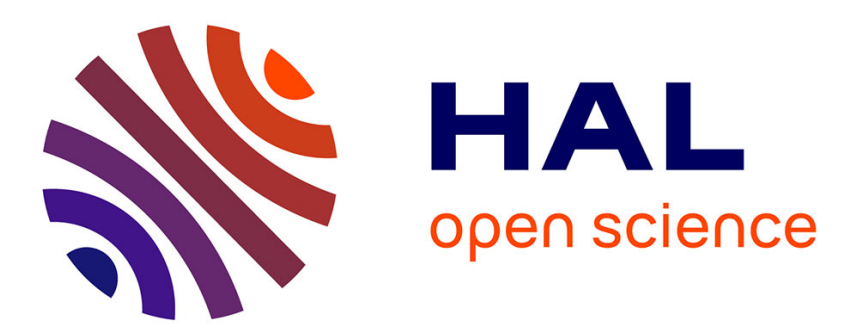

\title{
Increased expression of CD154 and FAS in SLE patients' lymphocytes
}

\author{
Maria Elena Manea, Ruediger B. Mueller, Doru Dejica, Ahmed Sheriff, Georg
} Schett, Martin Herrmann, Peter Kern

\section{- To cite this version:}

Maria Elena Manea, Ruediger B. Mueller, Doru Dejica, Ahmed Sheriff, Georg Schett, et al.. Increased expression of CD154 and FAS in SLE patients' lymphocytes. Rheumatology International, 2009, 30 (2), pp.181-185. 10.1007/s00296-009-0933-4 . hal-00568285

\section{HAL Id: hal-00568285 https://hal.science/hal-00568285}

Submitted on 23 Feb 2011

HAL is a multi-disciplinary open access archive for the deposit and dissemination of scientific research documents, whether they are published or not. The documents may come from teaching and research institutions in France or abroad, or from public or private research centers.
L'archive ouverte pluridisciplinaire HAL, est destinée au dépôt et à la diffusion de documents scientifiques de niveau recherche, publiés ou non, émanant des établissements d'enseignement et de recherche français ou étrangers, des laboratoires publics ou privés. 
Increased expression of CD154 and FAS in SLE patients' lymphocytes

Maria Elena Manea ${ }^{1 \ddagger}$, MD, Ruediger B. Mueller, ${ }^{2,}$, MD, Doru Dejica ${ }^{1}, \mathrm{PhD}$, Ahmed Sheriff $^{2}, \mathrm{PhD}$, Georg Schett ${ }^{2}, \mathrm{MD}$, Martin Herrmann ${ }^{2}$, PhD, Peter Kern ${ }^{4}$, MD

1 Department of Immunopathology. "Iuliu Hatieganu" University of Medicine and Pharmacy, Str Croitorilor no 19-21, 3400 Cluj-Napoca, Romania.

2 Department for Internal Medicine 3 and Institute for Clinical Immunology, University of Erlangen-Nürnberg, Germany

${ }^{3}$ Departement of Rheumatologie, Kantonsspital St. Gallen, Switzerland

${ }^{4}$ Franz von Prümmer Klinik, Bahnhofstraße 16, 97769 Bad Brückenau, Germany

${ }^{\ddagger}$ both authors equally contributed to the work

Address correspondence and reprint requests to: Ruediger B. Mueller MD, Department of Rheumatology, Kantonsspital St. Gallen, Rorschacherstr. 95, 9000 St. Gallen, Switzerland. Phone: +41 71 4941138, fax: +41 71 4946311, e-mail: ruediger.mueller@kssg.ch 


\section{ABSTRACT:}

Objectives: An increased level of apoptotic material and B cell activation leading to autoantibody-production are hallmarks of systemic lupus erythematodes (SLE). Increased FAS expression, apoptosis, and CD154 mediated signalling, enabling T-B cell interaction are involved in the pathogenesis of SLE. This study addresses the expression profile of CD154 and FAS in the peripheral blood of patients with SLE, rheumatoid arthritis (RA) and normal healthy control donors.

Methods: Surface markers on peripheral blood T and B cells from patients and healthy control donors were assessed by flow cytometry.

Results: Expression of CD154 and FAS were significantly increased in T and B cells of SLE patients as compared to healthy control donors and RA patients. In SLE and RA patients FAS expression strongly correlated with CD154 expression on $\mathrm{T}$ cells, which was not found in healthy control donors. FAS expression was also associated to the occurrence of anti-DNA antibodies.

Conclusion: We demonstrate high CD154 and FAS expression as a characteristic feature of SLE. This pattern may reflect simultaneous activation of apoptosis and activation of B-T cell interaction in SLE. 


\section{INTRODUCTION:}

SLE is a systemic autoimmune disease characterized by plasma B cells secreting nuclear autoantibodies (11), especially the pathognomonic anti-double-stranded DNA autoantibodies (anti-dsDNA). B and $\mathrm{T}$ cell interaction is required for the induction of humoral immunity. $\mathrm{T}$ cells can induce B cell proliferation and differentiation via ligation of CD154 by CD40 as a co-stimulatory molecule. The interaction of T and B cells in SLE is of major importance for the pathogenesis of the disease. CD154 hyperexpression in patients with active SLE was shown on $\mathrm{T}$ cells, B cells, and monocytes and correlated with disease activity (4). Interestingly, not only membrane bound but also soluble CD154 levels correlate with disease activity and enhanced titers of anti-dsDNA in patients with SLE, indicating a central role for the pathogenesis of CD154 (9). Underlining the importance of the CD154-CD40 interaction in SLE, treatment with a monoclonal Abs to CD154 significantly decreased disease activity in SLE patients (3). However, this treatment is associated with thromboembolic events (13) as a severe side effect leading to the hypothesis that CD154 cross-linking has effects aside costimulation.

An accumulation of apoptotic remnants in the tissue is observed in a subgroup of patients with SLE. FAS (CD95) and FAS-ligand interaction are associated with the induction of apoptosis (7). Stimulation of autoreactive B cells with anti-CD40 leads to an increase of FAS mediated apoptosis in vitro (8). In parallel, elevated plasma levels of sCD154 in patients with SLE increase CD95 expression on B cells (16). B cells, stimulated via CD40, are highly susceptible to FAS mediated apoptosis (8), when exposed to FAS-ligand expressing T cells (14). Consequently, we hypothesised that the CD154-CD40 mediated interaction and the up-regulation of FAS may occur simultaneously in SLE. We therefore measured the expression of FAS, CD40, and CD154 on T- and B-lymphocytes in a cohort of 52 patients with SLE, 32 patients with rheumatoid arthritis (RA), and 40 normal healthy control donors. The expression of these surface markers was correlated with each other and with the clinical course of SLE. 


\section{MATERIALS AND METHODS:}

Patient data. The patient population comprised 52 SLE and 32 RA patients. All patients were treated with disease modifying anti-rheumatic drugs (DMARDs) and/or corticosteroids. At the time of first analysis, all patients had an established disease. Disease activity differed, and was assessed by serum levels of $C$ reactive protein (CRP), erythrocyte sedimentation rates (10), and SLE disease activity index (SLEDAI) score for each patient and the use of medication was recorded (Table 1). 40 age and sex matched healthy donors served as controls. The study was approved by the University of Erlangen-Nuremberg Institutional Review Board, and written informed consent was obtained from all individuals before entering the study.

Immune phenotyping. Whole blood was stained for 30 minutes with saturating amounts of directly labelled mAbs. After automated lyses of the red blood cells (Q-Prep, Beckman Coulter, Cambridge, MA) the leucocytes were fixed with $1 \%$ paraformaldehyde and analyzed by flow cytometry (EPICS, Beckman Coulter, Cambridge, MA). The following phycoerythrin (PE), fluorescein-isothiocyanate (FITC), or CyChrome (Cy5) conjugated monoclonal antibodies were used: anti-CD4 (FITC/PE), anti-CD19 (FITC/PE/Cy5), (PE), anti-CD40 (FITC), anti-CD154 (FITC), and anti-CD95 (PE) (BD Pharmingen, Heidelberg, Germany). Unlabeled cells were used as controls for determining background- and autofluorescence.

Statistical analysis. Differences in data distribution were analyzed by two-tailed Student ttests. Correlation analysis was performed following the Pearson test. Comparison of two correlation analysis was assessed by the MetaAnalysis program 5.3 of Ralf Schwarzer; http://web.fu-berlin.de/gesund/gesu_engl/meta_e.htm. 


\section{RESULTS:}

\section{Expression of CD154 in SLE patients in comparison to RA and healthy control donors}

As ligation of the co-stimulatory molecule CD40 on B cells by its ligand CD154 on T cells plays a central role for $\mathrm{B}$ cell activation, we assessed the expression of both molecules by flow cytometry. The individual percentages of CD154 expressing B cells (CD19 ${ }^{\text {pos }}$, Figure 1A) and T helper cells (CD4 ${ }^{\text {pos }}$, Figure $\left.1 \mathrm{~B}\right)$ were significantly increased in patients with SLE compared to healthy control donors and patients with RA (B cells) or only compared to healthy control donors ( $\mathrm{T}$ helper cells). In detail, $0.6 \pm 0.7 \%$ of B cells from healthy control donors were positive for CD154, which was comparable to RA patients $(0.6 \pm 0.8 \%)$. In contrast, CD154 expression was significantly more frequent $(2.1 \pm 3.2 \%)$ in patients suffering from SLE. Similarly, CD154 expression was also increased in T helper cells of patients with SLE $(1.8 \pm 3.1 \%)$ as compared to healthy control donors $(0.6 \pm 0.8 \%)$. The data suggest that expression of the co-stimulatory molecule CD154 is increased in T and B cells of SLE patients. Thus, an increased expression of CD154 in B cells also discriminates SLE patients from other autoimmune diseases such (12) as RA.

\section{Expression of CD40 in SLE patients in comparison to RA and healthy control donors}

In parallel, we assessed CD40, the ligand of CD154 in peripheral blood cells of patients with SLE and RA as well as healthy control donors. CD40 expression was found in the majority of $B$ cells although there was a trend to a lower expression in SLE patients $(71.9 \pm 22.9 \%)$ than in healthy control donors $(85.4 \pm 14.1 \%)$ and RA patients $(79.2 \pm 18.6 \%)$ (Figure 1C). Thus, in contrast to the findings made for CD154 expression on SLE patient's B cells no discriminative propensity for CD40 expression could be found among RA patients, healthy donors and SLE patients.

\section{Expression of FAS in SLE patients in comparison to RA and healthy control donors}

An accumulation of apoptotic material is observed in various tissues of patients with SLE. As CD154 leads to an augmented expression of CD95, the expression of this pro-apoptotic molecule was also analyzed. FAS expression was increased in B cells (Figure 2A) and T cells (Figure 2B) from patients with SLE in comparison to healthy control donors. In detail, $38 \pm$ $20 \%$ of B cells and $66 \pm 14 \%$ of T cells expressed FAS in SLE patients. In healthy control donors only $19 \pm 7 \%$ of B cells and $51 \pm 9 \%$ of T cells expressed FAS. Importantly also RA patients displayed a lower expression of FAS in B cells $(25 \pm 14 \%)$, whereas its expression in T cells $(63 \pm 13 \%)$ was comparable to the expression in T cells of SLE patients. 


\section{Correlation of CD154 and FAS expression}

To delineate an association between CD154 and CD95 expression correlation analysis was performed. There was a significant correlation $(r=0.75 ; \mathrm{p}=0.001$, Figure $2 \mathrm{D})$ between the percentages of CD154 ${ }^{\text {pos }}$ and CD95 ${ }^{\text {pos }} \mathrm{T}$ cells in patients with SLE. To delineate whether this balance is similar a correlation analysis was also performed in healthy control donors. However, the correlation was much less pronounced $(r=0.35, p=0.0252$, Figure $2 E)$. In RA patients the correlation of $\mathrm{CD} 154^{\mathrm{pos}}$ and $\mathrm{CD} 95^{\mathrm{pos}} \mathrm{T}$ cells was similar as observed in SLE patients $(r=0.72, p=0.0001$, data not shown). Importantly, the correlations calculated for SLE and RA patients differed significantly $(\mathrm{p}=0.003)$ from the correlation calculated in healthy control donors. Thus, CD154 and CD95 expression strongly correlate in T cells of patients with SLE and RA.

As FAS is associated with the induction of apoptosis and an increase of apoptotic material is a hallmark of SLE, we next addressed whether increased FAS expression in $\mathrm{T}$ cells is associated with increased SLE disease activity. Indeed, patients with SLE and high FAS expression in T cells also display an increased amount of anti-DNA antibodies (Figure 2C). 


\section{DISCUSSION:}

In this study an increased expression of CD154 and FAS was denoted in peripheral blood T and B cells of patients with SLE as compared to healthy control donors. Moreover, expression of CD154 in B cells and FAS in T and B cells of SLE was higher than the expression of both molecules in lymphocytes of RA patients. Moreover there was tight correlation observed between CD154 and FAS expression in SLE and RA. These findings lead us to the hypothesis of an altered balance between CD154 and FAS on T cells in autoimmunity. FAS expression was also associated to the occurrence of anti-DNA antibodies a good marker of disease activity in SLE.

In coherence with various other publications, we also found an increased expression of CD154 on T cells (4) and B cells (6) in patients with SLE. In contrast to the published data (4) the increased expression of CD154 did not correlate with disease activity as assessed by SLEDAI, but corelated to the occurrence of anti-DNA antibodies levels, which is a surrogate marker for disease activity in SLE patients. Thus, we assume that CD154 plays an important role in patients with SLE that might lead to an increase of clinical disease activity as shown for the correlation of CD95 ${ }^{\mathrm{pos}}$ with CD154 on T cells on one hand and the occurrence of antiDNA antibodies on the other hand.

Treatment with neutralizing antibody against CD154 (13) leads to the occurrence of thromboembolic events. Since anti-phospholipid antibodies are associated with vascular events in SLE and of monoclonal antibodies to CD40 was linked to the anti-phospholipid antibodies in vivo (2), we analyzed whether increased levels of CD40 of CD154 expressing cells correlate with anti-phospholipid antibodies in our cohort. No association could be found (data not shown).

Autoantibodies against FAS-ligand can be found in 30\% of the patients with SLE. It has been suggested that this leads to an inhibition of FAS/FAS-L mediated apoptosis (15). In contrast, we demonstrated that the percentage of FAS expressing cells is increased on lymphocytes of patients with SLE. Whether this increase of FAS expression is a reaction on autoreactive antiFAS antibodies remains unclear. However, the level of apoptotic material in patients with SLE is increased. This may be due to a clearance defect of apoptotic material in patients with SLE (5). Alternatively, it could also be associated with an increased induction of apoptosis (12), potentially mediated by increased expression of FAS. As the expression level of FAS correlates with CD154 and, in parallel, the disease activity, an increase of disease activity may lead to an increase of apoptosis. In coherence, an increased expression of CD154 leads to 
an increased expression of FAS-ligand and induced, subsequently, apoptosis in biliary epithelial cells (1).

In summary, we showed that the expression of CD154 and FAS on SLE patients' T and B cells was increased and correlated with each other in tight correlation. FAS expression was also associated to the occurrence of anti-DNA antibodies a good marker of disease activity in SLE. 


\section{FIGURE LEGENDS:}

Figure 1: CD154 and CD40 expression in SLE: T and B cells were isolated from full blood by gradient centrifugation. The percentage of (A) CD154 ${ }^{\text {pos }} \mathrm{B}$ and (B) CD4+ T cells and (C) CD $40^{\text {pos }}$ B cells was assessed by flow cytometry. All data are represented as dots for every individual patient and healthy control donor. Percentages of cells expressing certain surface markers are demonstrated for patients with RA and SLE represented on the first and second and such found on healthy control donors (NHD) on the right column, representatively. Statistical differences were calculated employing the student's T-test.

Figure 2: CD95 expression in SLE: T and B cells were isolated from full blood by gradient centrifugation. Percentages of CD95 ${ }^{\text {pos }}$ cells among (A) CD4 ${ }^{\text {pos }} \mathrm{T}$ and (B) CD19 ${ }^{\text {pos }} \mathrm{T}$ cells were assessed with flow cytometry. All data are represented as dots for every individual patient in two columns. Percentages of cells expressing CD95 are demonstrated for patients with RA, SLE, and healthy control donors (NHD). Statistical differences were calculated employing the Student's T-test. (C) Patients with SLE were separated into two groups: negative (left) and positive (right) for anti-DNA antibodies. Percentages of CD95 ${ }^{\text {pos }} \mathrm{T}$ dells are demonstrated for both groups as means \pm standard deviation. Statistical differences were calculated employing the Student's T-test. Correlation analysis of CD154 and CD95 expression on $\mathrm{T}$ cells of SLE patients (D) and healthy control donors (E): Every dot represents the individual expressional percentage found within one patient for CD154 and CD95 on T cells. The correlation line is depicted as a line with the $95 \%$ confidence interval within the graph.

\section{ACKNOLEDGEMENTS:}

This work was supported by "Deutsche Forschungsgemeinschaft" SFB 643 (project B5), by the Interdisciplinary Centre for Clinical Research (IZKF) (project number A4 and N2) at the University Hospital of the University of Erlangen-Nuremberg, by the European Commissions [E.U. (QLK3-CT-2002-02017_APOCLEAR)], by the Lupus Erythemathodes Selbsthilfegemeinschaft e.V., by the "Responsif GmbH" Erlangen, by the "Doktor Robert Pfleger" Foundation, Bamberg, by the ELAN-Fond of the university of Erlangen Nuremberg (Pro.-Nr. 53410026), A grand dedicated to Maria Elena Manea and Doru Deica by the Alexander von Humboldt Foundation.

\section{REFERENCES:}


1. Afford SC, Ahmed-Choudhury J, Randhawa S, Russell C, Youster J, Crosby HA, Eliopoulos A, Hubscher SG, Young LS, Adams DH (2001) CD40 activation-induced, Fas-dependent apoptosis and NF-kappaB/AP-1 signaling in human intrahepatic biliary epithelial cells. FASEB J 15:2345-2354 Medline. doi:10.1096/fj.01-0088com

2. Aleksandrova EN, Novikov AA, Popkova TV, Reshetniak TM, Novikova DS, Kliukvina NG, Il'ina AE, Mach ES, Volkov AV, Nasonov EL (2006). Ter Arkh 78:35-39. Soluble CD40 ligand in systemic lupus erythematosus and antiphospholipid syndrome Medline.

3. Boumpas DT, Furie R, Manzi S, Illei GG, Wallace DJ, Balow JE, Vaishnaw A (2003) A short course of BG9588 (anti-CD40 ligand antibody) improves serologic activity and decreases hematuria in patients with proliferative lupus glomerulonephritis. Arthritis Rheum 48:719-727 Medline. doi:10.1002/art.10856

4. Desai-Mehta A, Lu L, Ramsey-Goldman R, Datta SK (1996) Hyperexpression of CD40 ligand by $\mathrm{B}$ and $\mathrm{T}$ cells in human lupus and its role in pathogenic autoantibody production. J Clin Invest 97:2063-2073 Medline. doi:10.1172/JCI118643

5. Gaipl US, Voll RE, Sheriff A, Franz S, Kalden JR, Herrmann M (2005) Impaired clearance of dying cells in systemic lupus erythematosus. Autoimmun Rev 4:189-194 Medline. doi:10.1016/j.autrev.2004.10.007

6. Grammer AC, Bergman MC, Miura Y, Fujita K, Davis LS, Lipsky PE (1995) The CD40 ligand expressed by human B cells costimulates B cell responses. J Immunol 154:49965010 Medline.

7. Haas JP, Grunke M, Frank C, Kolowos W, Dirnecker D, Leipold G, Hieronymus T, Lorenz HM, Herrmann M (1998) Increased spontaneous in vitro apoptosis in double negative $T$ cells of humans with a fas/apo-1 mutation. Cell Death Differ 5:751-757 Medline. doi:10.1038/sj.cdd.4400426

8. Hirose S, Yan K, Abe M, Jiang Y, Hamano Y, Tsurui H, Shirai T (1997) Precursor B cells for autoantibody production in genomically Fas-intact autoimmune disease are not subject to Fas-mediated immune elimination. Proc Natl Acad Sci USA 94:9291-9295 Medline. doi:10.1073/pnas.94.17.9291

9. Kato K, Santana-Sahagun E, Rassenti LZ, Weisman MH, Tamura N, Kobayashi S, Hashimoto H, Kipps TJ (1999) The soluble CD40 ligand sCD154 in systemic lupus erythematosus. J Clin Invest 104:947-955 Medline. doi:10.1172/JCI7014

10. Lederer JA, Perez VL, DesRoches L, Kim SM, Abbas AK, Lichtman AH (1996) Cytokine transcriptional events during helper T cell subset differentiation. J Exp Med 184:397-406 Medline. doi:10.1084/jem.184.2.397

11. Lipsky PE (2001) Systemic lupus erythematosus: an autoimmune disease of B cell hyperactivity. Nat Immunol 2:764-766 Medline. doi:10.1038/ni0901-764 
12. Lorenz HM, Grunke M, Hieronymus T, Herrmann M, Kuhnel A, Manger B, Kalden JR (1997) In vitro apoptosis and expression of apoptosis-related molecules in lymphocytes from patients with systemic lupus erythematosus and other autoimmune diseases. Arthritis Rheum 40:306-317 Medline. doi:10.1002/art.1780400216

13. Nakamura M, Tanaka Y, Satoh T, Kawai M, Hirakata M, Kaburaki J, Kawakami Y, Ikeda Y, Kuwana M (2006) Autoantibody to CD40 ligand in systemic lupus erythematosus: association with thrombocytopenia but not thromboembolism. Rheumatology (Oxford) 45:150-156 Medline. doi:10.1093/rheumatology/kei118

14. Schattner EJ, Elkon KB, Yoo DH, Tumang J, Krammer PH, Crow MK, Friedman SM (1995) CD40 ligation induces Apo-1/Fas expression on human B lymphocytes and facilitates apoptosis through the Apo-1/Fas pathway. J Exp Med 182:1557-1565 Medline. doi:10.1084/jem.182.5.1557

15. Suzuki N, Ichino M, Mihara S, Kaneko S, Sakane T (1998) Inhibition of Fas/Fas ligandmediated apoptotic cell death of lymphocytes in vitro by circulating anti-Fas ligand autoantibodies in patients with systemic lupus erythematosus. Arthritis Rheum 41:344353 Medline. doi:10.1002/1529-0131(199802)41:2<344::AID-ART19>3.0.CO;2-J

16. Vakkalanka RK, Woo C, Kirou KA, Koshy M, Berger D, Crow MK (1999) Elevated levels and functional capacity of soluble CD40 ligand in systemic lupus erythematosus sera. Arthritis Rheum 42:871-881 Medline. doi:10.1002/15290131(199905)42:5<871::AID-ANR5>3.0.CO;2-J
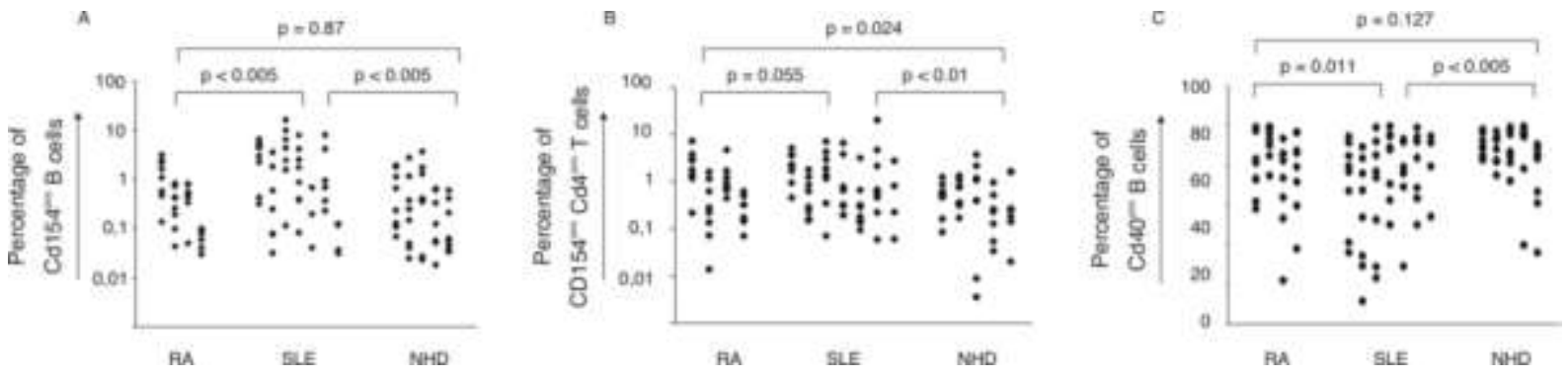

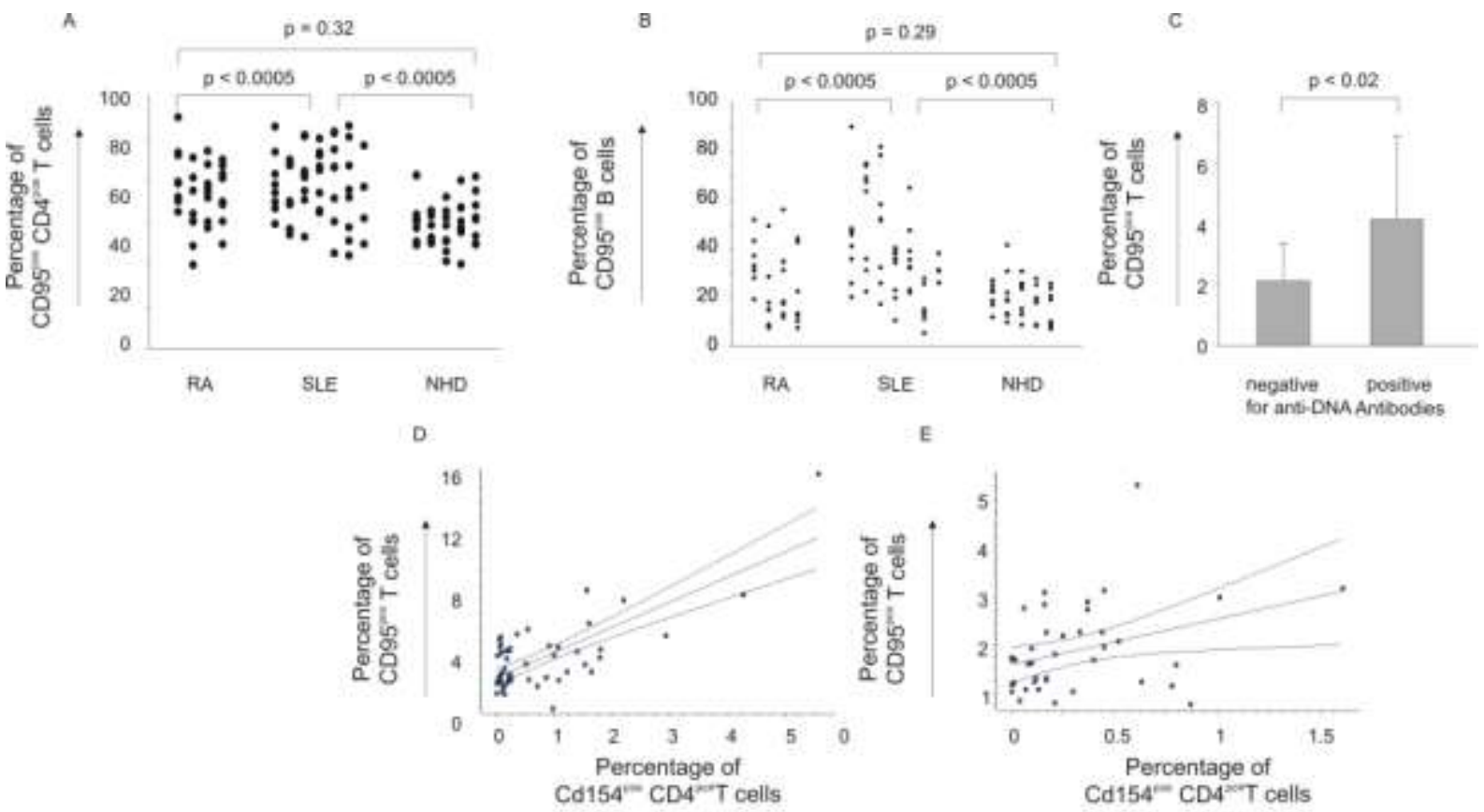

Table 1. Patient data

\begin{tabular}{lccc}
\hline \hline & $\begin{array}{c}\text { AA patients } \\
\text { mean (range) }\end{array}$ & $\begin{array}{c}\text { SLE Patients } \\
\text { mean (range) }\end{array}$ & $\begin{array}{c}\text { NHD } \\
\text { mean (range) }\end{array}$ \\
\hline Number & 32 & 52 & 40 \\
Age & $54,6(27-69)$ & $45,3(20-72)$ & $36,3(22-68)$ \\
Sex (female/male) & $23 t, 9 \mathrm{~m}$ & $45 t, 7 \mathrm{~m}$ & $27 t, 13 \mathrm{~m}$ \\
C reactive protein & $0.5(0-1.5)$ & $2.5(0.1-17)$ & n.d. \\
SLEDAl & n.a. & $4.3(0-16)$ & n.a. \\
Anti-DNA & n.d. & $60.5(0-1380)$ & n.d. \\
ANA & n.d. & $1974(0-10000)$ & n.d. \\
\hline \hline
\end{tabular}

